\title{
Successful treatment of erythropoietin-producing advanced renal cell carcinoma after targeted therapy using sunitinib: Case report and review of the literature
}

\author{
KOSUKE UEDA, SHIGETAKA SUEKANE, KATSUAKI CHIKUI, MAKOTO NAKIRI, FUKUKO MORIYA, \\ TOKUMASA HAYASHI, JIRO MIYAJIMA and KEI MATSUOKA
}

Department of Urology, Kurume University School of Medicine, Kurume, Fukuoka 830-0011, Japan

Received June 6, 2012; Accepted July 31, 2012

DOI: $10.3892 / \mathrm{mco} .2012 .5$

\begin{abstract}
In general, only $\leq 5 \%$ of patients with renal cell carcinoma (RCC) develop paraneoplastic erythropoietin (EPO) overproduction-induced polycythemia. However, a number of reports on EPO-producing RCC are available. The present study aimed to report the first case of a patient demonstrating a therapeutic effect on EPO-producing advanced RCC, subsequent to targeted pre-surgical sunitinib therapy, with a review of the literature. The patient involved was a 62-year-old male who presented with a malformation of the left scrotum. Examination revealed a tumor of $73 \mathrm{~mm}$ in diameter along with lymph node metastasis. The histological examination indicated a clear cell RCC containing viable cells as well as hemorrhage and necrosis. EPO in cancer cells was confirmed by immunohistochemistry. Subsequently, a case of EPO-producing RCC with polycythemia was diagnosed. The EPO-producing RCC was successfully treated following targeted presurgical therapy with sunitinib.
\end{abstract}

\section{Introduction}

Renal cell carcinoma (RCC) is a relatively common tumor, accounting for $\sim 3 \%$ of the adult malignancies (1). In Japan, a previous nationwide study investigating $\mathrm{RCC}$ revealed 7,405 patients (5,063 males, 2,342 females) with a positive diagnosis in 2002 (2).

In general, only $\leq 5 \%$ of RCC patients develop paraneoplastic erythropoietin (EPO) overproduction-induced polycythemia (2). However, several studies are available on

Correspondence to: Dr Kosuke Ueda, Department of Urology, Kurume University School of Medicine, 67 Asahi-machi, Kurume, Fujuoka 830-0011, Japan

E-mail: ueda_kousuke@med.kurume-u.ac.jp

Abbreviations: CT, computer tomography; EPO, erythropoietin; MRI, magnetic resonance imaging; RCC, renal cell carcinoma

Key words: erythropoietin, renal cell carcinoma, sunitinib, polycythemia
EPO-producing RCC. In the present study, the first case of a patient exhibiting a therapeutic effect on EPO-producing advanced RCC subsequent to targeted pre-surgical sunitinib therapy is reported, with a review of the literature.

\section{Case report}

A 62-year-old male individual identified a malformation of the left scrotum. On physical examination, a left unilateral varicocele was diagnosed, and redness of the face was observed. Abdominal ultrasonography and computer tomography (CT) scans detected a tumor of $73 \mathrm{~mm}$ in diameter at the upper pole of the left kidney and tumor embolism in the renal vein and the inferior vena cava (Fig. 1). Furthermore, lymph node metastasis was detected in the left hilus renalis. A thoracic CT scan demonstrated several nodules in the lung, while the laboratory analysis showed red blood cell (RBC) count, 682x $10^{6} / \mathrm{mm}^{3}$; hemoglobin $(\mathrm{Hb}), 21.3 \mathrm{~g} / \mathrm{dl}$ and hematocrit $(\mathrm{Ht}) 61.6 \%$. The patient's serum EPO level was $35.8 \mathrm{mU} / \mathrm{ml}$ (normal range, 8-36 $\mathrm{mU} / \mathrm{ml}$ ). Written consent was obtained from the patient prior to inclusion in this case study.

The percutaneous biopsy of the left renal tumor was performed in an outpatient setting under ultrasonographic guidance for the histological diagnosis. Subsequent to microscopic examination, the histology of the renal tumor showed clear cell RCC (Fig. 2), which was classified as clinical stage T3bN1M1, according to TNM classification. The patient was classifiated to be at intermediate risk, according to the Memorial Sloan-Kettering Cancer Center (MSKCC) criteria. The patient first received phlebotomy 3 times/week for polycythemia and then sunitinib (50 mg/day) was administered for 4 weeks at 6-week intervals as pre-surgical therapy. However, as grade 3 liver dysfunction emerged after 12 days of the first treatment cycle, sunitinib administration was transiently terminated and reinitiated at $37.5 \mathrm{mg} /$ day upon improvement. Although grade 1 dysgeusia was observed as a further adverse event during the treatment, sunitinib administration was well-tolerated with no grade 4 treatment-related adverse events. Moreover, white blood cell (WBC) and platelet counts were normal. During sunitinib treatment, hemoglobin and hematocrit counts remained within the normal ranges (11-13 g/dl and 33-46\%, respectively). 
A

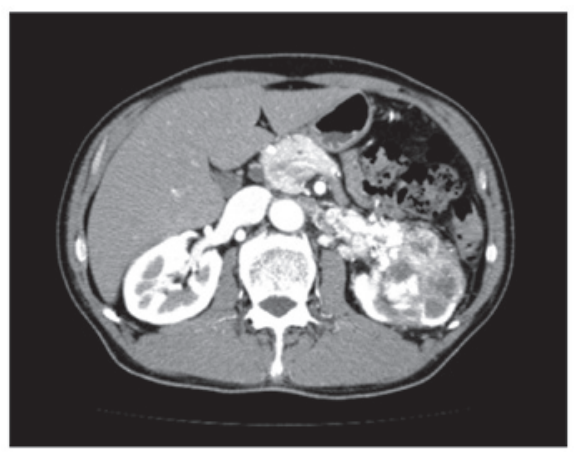

B

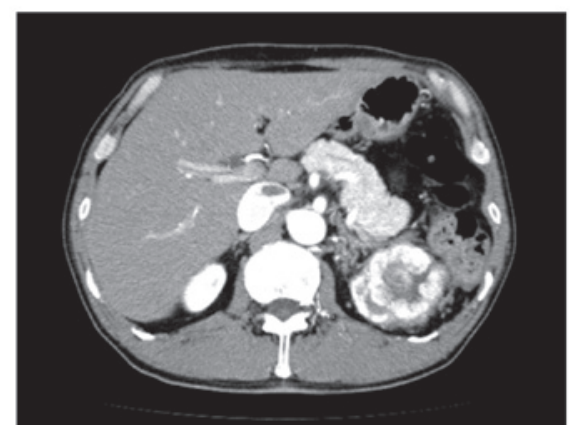

Figure 1. CT scan at diagnosis. Abdominal CT revealed (A) a 73-mm diameter heterogeneously enhanced mass at the upper pole of the left kidney with (B) embolism in the renal vein and inferior vena cava.

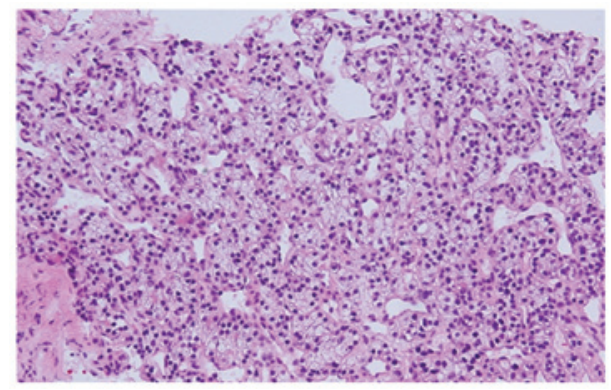

Figure 2. Microscopic appearance of the tumor biopsy specimen showed a clear cell renal cell carcinoma, which proliferated in an alveolar pattern.

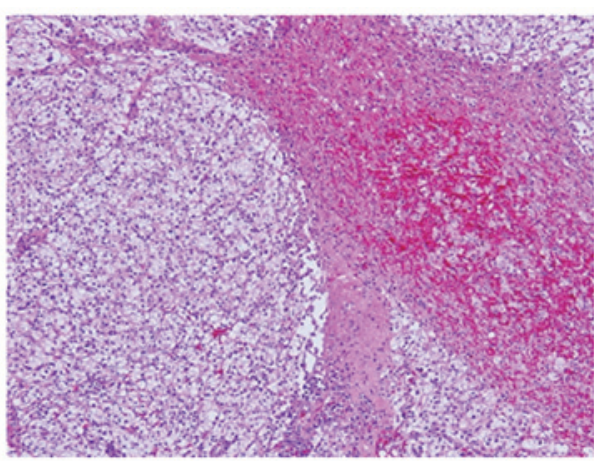

Figure 3. Microscopic appearance of tissue slides from the renal tumor is shown. Histological examination of the tumor showed clear cell renal cell carcinoma. Although most of the tumor had viable cells, hemorrhage and necrosis were present. (H\&E; magnification, $\mathrm{x} 100)$.

After 3 cycles of treatment, $20.4 \%$ regression of the tumor was observed on CT based on the response evaluation criteria
A

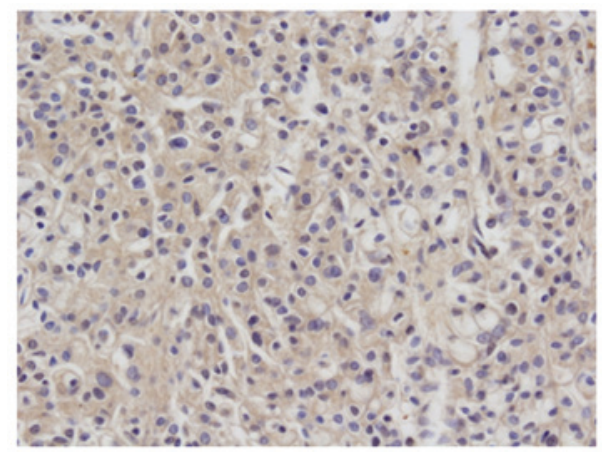

B

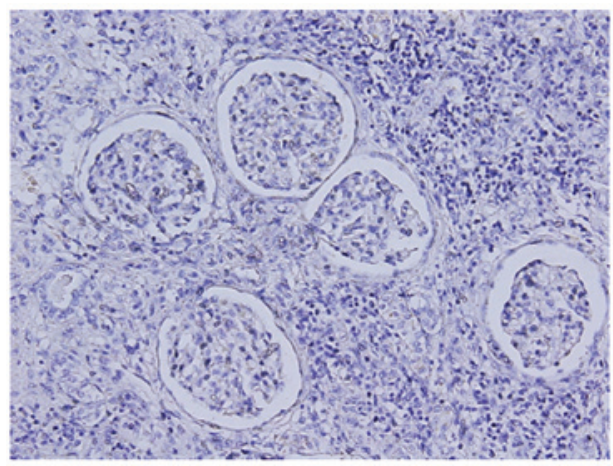

Figure 4. (A) Immunohistochemical staining with erythropoietin (EPO) showed that the cytoplasm of tumor cells was diffuse-positive. (B) Normal kidney tissues were diffuse-negative.

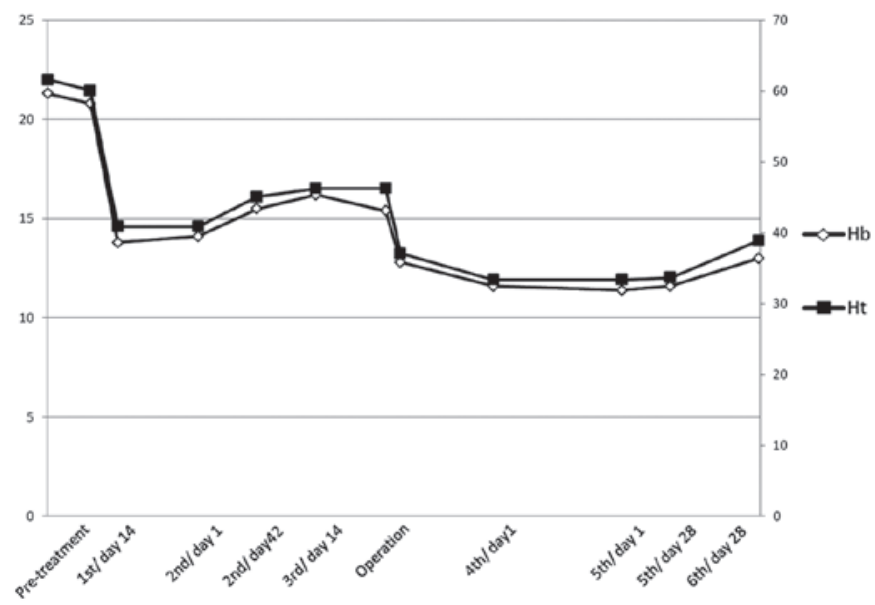

Figure 5. Pre- and post-treatment serum hemoglobin $(\mathrm{Hb})$ and hematocrit (Ht) levels are shown.

in solid tumors (RECIST), while the intravenous tumor embolism had decreased in size. A radical nephrectomy and lymph node resection were performed through an abdominal approach 2 weeks subsequent to the cessation of sunitinib. At the time of the nephrectomy, adherence surrounding the left hilus renalis and the distention of the left renal vein, as well as the gonadal vessels, were observed. Although a left renal vein tumor embolism was detected, no embolism was detected in the inferior vena cava. The surgery lasted for $5 \mathrm{~h} 32 \mathrm{~min}$, with an estimated blood loss of 2,040 $\mathrm{ml}$. During the perioperative period, part of the wound was dissociated, without additional complications. 
Table I. Patient characteristics $(n=17)$.

\begin{tabular}{|c|c|}
\hline Characteristics & Value \\
\hline Median age, years (range) & $57(44-83)$ \\
\hline \multicolumn{2}{|l|}{ Gender, $\mathrm{n}$} \\
\hline Males & 14 \\
\hline Females & 3 \\
\hline Median RBC, $10^{4} / \mu 1$ (range) & $709(570-791)$ \\
\hline Median Hb, g/dl (range) & $19.2(17.2-23.2)$ \\
\hline Median Ht, \% (range) & $59.25(52.1-70)$ \\
\hline Nephrectomy, $\mathrm{n}$ & 17 \\
\hline Other therapy, $\mathrm{n}$ & 9 \\
\hline $\mathrm{IFN} \alpha$ & 5 \\
\hline UFT & 2 \\
\hline Embolization, $\mathrm{n}$ & 1 \\
\hline Sunitinib, $\mathrm{n}$ & 1 \\
\hline \multicolumn{2}{|l|}{ Histological type, $\mathrm{n}$} \\
\hline Clear cell type & 14 \\
\hline Unknown & 3 \\
\hline \multicolumn{2}{|l|}{ Stage, $n$} \\
\hline $\mathrm{I}$ & 2 \\
\hline II & 2 \\
\hline III & 4 \\
\hline IV & 7 \\
\hline Unknown & 2 \\
\hline
\end{tabular}

RBC, red blood cell; Hb, hemoglobin; Ht, hematocrit; IFN $\alpha$, interferon $\alpha$; UFT, tegafur-uracil.
The histological examination of the tumor showed a clear cell RCC, which had proliferated in an alveolar pattern (Fig. 3). Although most of the tumor contained viable cells, hemorrhage and necrosis were detected. The capsular invasion of the tumor was not observed, rather viable RCC cells were detected in the left renal vein and the gonadal vessels. Furthermore, the lymph node of the hilus renalis contained viable RCC cells. Immunohistochemistry demonstrated EPO in cancer cells, but not in normal kidney tissues (Fig. 4). From the abovementioned result, this was diagnosed as a case of EPO-producing RCC with polycythemia. Subsequent to nephrectomy, sunitinib was re-administered at $37.5 \mathrm{mg}$ per day. The metastatic lesion of the lung was stable at 6 months after surgery, while the hemoglobin and hematocrit were maintained within normal ranges (Fig. 5).

\section{Discussion}

EPO, a glycoprotein produced mainly by the kidney, controls erythropoiesis (3). Increased EPO production results in secondary erythrocytosis, which has been reported in a variety of tumors including RCC (4), hepatocellular carcinoma (5) and cerebellar hemangioblastoma (6). Additionally, EPO-producing renal cyst, metanephric adenoma, renal hemangioma and polycythemia-induced hydronephrosis have been thoroughly described (7). In general, only $\leq 5 \%$ of patients with RCC develop paraneoplastic EPO overproduction-induced polycythemia, while approximatrly $35 \%$ develop significant anemia $(4,7,8)$. The glycoprotein hormone EPO is an essential viability and growth factor for the erythrocytic progenitors. The oxygen-dependent regulation of the EPO gene expression is postulated to be controlled by a

Table II. Study characteristics.

\begin{tabular}{|c|c|c|c|c|c|c|c|c|}
\hline $\begin{array}{l}\text { Patient } \\
\text { number }\end{array}$ & Study (Refs.) & Year & $\begin{array}{l}\text { Age (years)/ } \\
\text { gender }\end{array}$ & $\operatorname{RBC}\left(10^{4} / \mu 1\right)$ & $\mathrm{Hb}(\mathrm{g} / \mathrm{dl})$ & $\mathrm{Ht}(\%)$ & Treatment & Stage \\
\hline 1 & Fujii et al (18) & 1976 & 66/M & 650 & 20.5 & 63.4 & $\mathrm{RN}$ & NS \\
\hline 2 & Hokayama et al (18) & 1976 & 64/M & NS & 21.3 & NS & RN & IV \\
\hline 3 & Shiga et al (18) & 1981 & $44 / \mathrm{M}$ & 682 & 21.5 & 65.0 & $\mathrm{RN}$ & IV \\
\hline 4 & Ishihara et al (18) & 1988 & $56 / \mathrm{F}$ & 682 & 18 & 54.3 & $\mathrm{RN}$ & NS \\
\hline 5 & Ishibashi et al (18) & 1990 & $58 / \mathrm{M}$ & 631 & 17.2 & 52.1 & $\mathrm{RN}, \mathrm{IFN} \alpha, \mathrm{UFT}$ & IV \\
\hline 6 & Kanamaru et al (18) & 1992 & $51 / \mathrm{M}$ & 762 & 18.4 & 59.2 & $\mathrm{RN}$ & III \\
\hline 7 & Furukawa et al (18) & 1992 & $83 / \mathrm{M}$ & 737 & 17.9 & 60.5 & RN, UFT & IV \\
\hline 8 & Yomogi et al (24) & 1994 & $56 / \mathrm{M}$ & 712 & 23.2 & 70.0 & $\mathrm{RN}$ & III \\
\hline 9 & Teishima et al (25) & 1996 & $52 / \mathrm{M}$ & 660 & 19.4 & 59.2 & $\mathrm{RN}, \mathrm{IFN} \alpha$ & IV \\
\hline 10 & Yoshida et al (16) & 1997 & $59 / \mathrm{F}$ & 709 & 17.9 & 55.5 & $\mathrm{RN}$ & II \\
\hline 11 & Sato et al (26) & 1998 & $56 / \mathrm{F}$ & 714 & 19 & 59.3 & $\mathrm{RN}$ & III \\
\hline 12 & Noguchi et al (17) & 1999 & $57 / \mathrm{M}$ & 789 & 20.4 & 65.0 & $\mathrm{RN}$ & I \\
\hline 13 & Morita et al (27) & 2001 & $52 / \mathrm{M}$ & 791 & 19.4 & 61.3 & $\mathrm{RN}, \mathrm{IFN} \alpha$ & IV \\
\hline 14 & Okuyama et al (18) & 2002 & $46 / \mathrm{M}$ & 775 & 18.9 & 58.5 & $\mathrm{RN}, \mathrm{IFN} \alpha$ & III \\
\hline 15 & Rad et al (19) & 2008 & $76 / \mathrm{M}$ & NS & NS & 55.0 & $\mathrm{RN}, \mathrm{IFN} \alpha$ & I \\
\hline 16 & Hirose et al (28) & 2011 & $80 / \mathrm{M}$ & 570 & 18.7 & 55.2 & Embolization, RN & II \\
\hline 17 & Present case & 2012 & $62 / \mathrm{M}$ & 682 & 21.3 & 61.6 & Sunitinib, RN & IV \\
\hline
\end{tabular}

M, male; F, female; RBC, red blood cell; NS, not significant; Hb, hemoglobin; Ht, hematocrit; RN, radical nephrectomy; IFN $\alpha$, interferon $\alpha$; UFT, tegafur-uracil. 
hypoxia-inducible transcription factor- $1 \alpha$ (HIF-1 $\alpha)$. HIF-1 $\alpha$ interacts with the Von Hippel-Lindau (VHL) protein and is degraded by ubiquitin-mediated proteolysis in the presence of oxygen. Accumulation occurs under hypoxia due to the inhibition of its proteolytic degradation through the ubiquitin proteasome pathway, while promoting EPO gene transcription. Furthermore, VHL gene product (pVHL) loss has also been detected in $45-80 \%$ of clear cell RCC cases (9-11). RCC continuously activates the HIF pathway, while promoting EPO gene transcription (12).

Recent studies have reported that the receptor tyrosine kinase inhibitors of the vascular endothelial growth factor (VEGF) receptor family, such as sunitinib and sorafenib, induce EPO upregulation (13-15). However, in the present study, the administration of sunitinib was successful in inhibiting tumor progression, as well as controlling polycythemia. The present case was most likely controlled by damaging cancer cells and decreasing EPO production to inhibit angiogenesis by not signaling the HIF-VEGF or HIF-EPO pathways. Hokayama et al (18) suggested various criteria for erythropoietin-producing tumors: i) coexistence of the tumor and polycythemia, ii) polycythemia consumption following tumor resection, iii) increasing activation of serum or urinary EPO, iv) EPO activation from tumor extracts, v) no additional evidence of the cause of erythrocytosis or -poiesis, including mRNA in the immunohistochemistry as additional evidence.

In the present study, the immunohistochemical staining of tumor tissue also revealed EPO production in tumor cells subsequent to pre-surgical sunitinib therapy. The mechanism of EPO elevation in RCC has been shown to be due to the fact that the tumor is self-producing, as well as to EPO overproduction in normal renal tissue resulting in local hypoxia arising from the tumor. However, in the present study, immunohistochemical staining of normal renal tissue was detected. To the best of our knowledge, 17 patients (14 males and 3 females; median age, 57 years; range, 44-83), including the present case, have been reported thus far with EPO-producing RCC (16-19) (Tables I and II). Most of these patients are male, with the most common histological cell type being RCC (14 cases). Due to the limited number of reports available the prognosis has been insufficient, although in their studies, Sufrin et al (20) and Ljungherg et al (21) demonstrated that $63(36 / 57)$ and $33 \%(55 / 167)$ of RCC cases showed elevated serum EPO, respectively, whereas a few cases showed polycythemia $(20,21)$. Several studies have delineated that $\sim 8 \%$ renal tumors show polycythemia, while $\sim 1.2 \%$ of the cases show serum EPO elevation. Michael et al (22) reported that the immunohistological expression of EPO in RCC is adversely associated with poor prognosis (22). Furthermore, Westenfelder and Baranowski (4), as well as Westenfelder et al (23) showed that EPO is likely to stimulate malignant tumor cells $(4,23)$.

At present, there are few studies available using targeted therapy for EPO-producing advanced RCC. This is the first report to demonstrate a successful treatment of EPO-producing advanced RCC subsequent to targeted presurgical sunitinib therapy. Although the mechanism and the effect of the multitargeted tyrosine kinase inhibitor on EPO-producing RCC remain to be determined, the present case suggests that sunitinib is likely to inhibit tumor progression, as well as control polycythemia. Consequently, additional cases are necessary to confirm these results.

\section{References}

1. Chow WH, Devesa SS, Warren JL and Fraumeni JF Jr: Rising incidence of renal cell carcinoma in the United States. JAMA 281: 1628-1638, 1999.

2. Marumo K, Kanayama H, Miyao N, Nakazawa H, Ozono S, Horie S, Nagamori S, Igarashi T, Hasegawa M, Kimura G, Nakao M, Nakamoto T and Naito S: Prevalence of renal cell carcinoma: a nation-wide survey in Japan, 2002. Int J Urol 14: 479-482, 2007.

3. Da Silva JL, Lacombe C, Bruneval P, Casadevall N, Leporrier M, Camilleri JP, Bariety J, Tambourin P and Varet B: Tumor cells are the site of erythropoietin synthesis in human renal cancers associated with polycythemia. Blood 75: 577-582, 1990.

4. Westenfelder C and Baranowski RL: Erythropoietin stimulates proliferation of human renal carcinoma cells. Kidney Int 58: 647-657, 2000

5. Muta H, Funakoshi A, Baba T, Uike N, Wakasugi H, Kozuru M and Jimi A: Gene expression of erythropoietin in hepatocellular carcinoma. Intern Med 33: 427-431, 1994.

6. Trimble M, Caro J, Talalla A and Brain M: Secondary erythrocytosis due to a cerebellular hemangioblastoma: demonstration of erythropoietin mRNA in the tumor. Blood 78: 599-601, 1991.

7. Nseyo UO, Williams PD and Murphy GP: Clinical significance of erythropoietin levels in renal carcinoma. Urology 28: 301-306, 1986.

8. Motzer RJ, Bander NH and Nanus DM: Renal-cell carcinoma. N Engl J Med 335: 865-875, 1996.

9. Linehan WM, Pinto PA, Srinivasan R, Merino M, Choyke P, Choyke L, Coleman J, Toro J, Glenn G, Vocke C, Zbar B, Schmidt LS, Bottaro D and Neckers L: Identification of the genes for kidney cancer: opportunity for disease-specific targeted therapeutics. Clin Cancer Res 13: 671-679, 2007.

10. Prowse AH, Webster AR, Richards FM, Richard S, Olschwang S, Resche F, Affara NA and Maher ER: Somatic inactivation of the VHL gene in von Hippel-Lindau disease tumours. Am J Hum Genet 60: 765-771, 1997.

11. Na X, Wu G, Ryan CK, Schoen SR, di'Santagnese PA and Messing EM: Overproduction of vascular endothelial growth factor related to von Hippel-Lindau tumour suppressor gene mutations and hypoxia-inducible factor $1 \alpha$ expression in renal cell carcinoma. J Urol 170: 588-592, 2003.

12. Gong K, Zhang N, Zhang K and Na Y: The relationship of erythropoietin overexpression with von Hippel-Lindau tumour suppressor gene mutations between hypoxia-inducible factor-1 $\alpha$ and $-2 \alpha$ in sporadic clear cell renal carcinoma. Int J Mol Med 26: 907-912, 2010.

13. Alexandrescu DT, McClure R, Farzanmehr H and Dasanu CA: Secondary erythrocytosis produced by the tyrosine kinase inhibitors sunitinib and sorafenib. J Clin Oncol 26: 4047-4078, 2008.

14. Vroling L, van der Veldt AA, de Haas RR, Haanen JB, Schuurhuis GJ, Kuik DJ, van Cruijsen H, Verheul HM, van den Eertwegh AJ, Hoekman K, Boven E, van Hinsbergh VW and Broxterman HJ: Increased numbers of small circulating endothelial cells in renal cell cancer patients treated with sunitinib. Angiogenesis 12: 69-79, 2009.

15. Ebos JM, Lee CR, Christensen JG, Mutsaers AJ and Kerbel RS: Multiple circulating proangiogenic factors induced by sunitinib malate tumor-independent and correlate with antitumor efficacy. Proc Natl Acad Sci USA 104: 17069-17074, 2007.

16. Yoshida T, Kin S and Kounami T: A case of erythropoietinproducing renal cell carcinoma proved by immunohistochemistry. Hinyokika Kiyo 43: 339-342, 1997 (In Japanese).

17. Noguchi Y, Goto T, Yufu Y, Uike N, Hasegawa Y, Fukuda T, Jimi A and Funakoshi A: Gene expression of erythropoietin in renal cell carcinoma. Intern Med 38: 991-994, 1999.

18. Okuyama $M$, Nishihara $M$, Hashimoto $H$, Kaneko $S$ and Yachiku S: A case of erythropoietin-producing renal cell carcinoma with polycythemia. Hinyokika Kiyo 48: 531-534, 2002 (In Japanese).

19. Rad FH, Ulusakarya A, Gad S, Sibony M, Juin F, Richard S, Machover D and Uzan G: Novel somatic mutations of the VHL gene in an erythropoietin-producing renal carcinoma associated with secondary polycythemia and elevated circulating endothelial progenitor cells. Am J Hematol 83: 155-158, 2008. 
20. Sufrin G, Mirand EA, Moore RH, Chu TM and Murphy GP: Hormones in renal cancer. J Urol 117: 433-438, 1997.

21. Ljungherg B, Rasmuson T and Grankvist K: Erythropoietin in renal cell carcinoma: evaluation of its usefulness as a tumor marker. Eur Urol 21: 160-163, 1992.

22. Michael A,Politi E, Havranek E, Corbishley C, Karapanagiotou L, Anderson C, Relph K, Syrigos KN and Pandha H: Prognostic significance of erythropoietin expression in human renal cell carcinoma. BJU Int 100: 291-294, 2007.

23. Westenfelder C, Biddle DL and Baranowski RL: Human, rat, and mouse kidney cells express functional erythropoietin receptors. Kidney Int 55: 808-820, 1999.

24. Yomogi H, Odajima K, Nakamura H, et al: A case of erythropoietin-producing renal cell carcinoma. Rinsho Hinyokika 48: 139-141, 1994.
25. Teishima T, Sumi H, Ikemoto H, Himeno Y and Ishino T: A case of erythropoietin-producing renal cell carcinoma. Jpn J Urol Surg 9: 1181-1183, 1996.

26. Sato T, Hukui J, Okamoto S, et al: A case of renal cell carcinoma with polycythemia. Jpn J Urol Surg 11: 85-87,1998.

27. Morita S, Watanabe K, Sakamoto H, et al: A case of erythropoietin-producing renal cell carcinoma. Rinsho Hinyokika 55: 651-653, 2001.

28. Hirose Y, Ando R, Nakane A, Akita H and Okamura T: A case of erythropoietin-producing renal cell carcinoma. Jpn J Urol Surg 24: 187-190, 2011. 